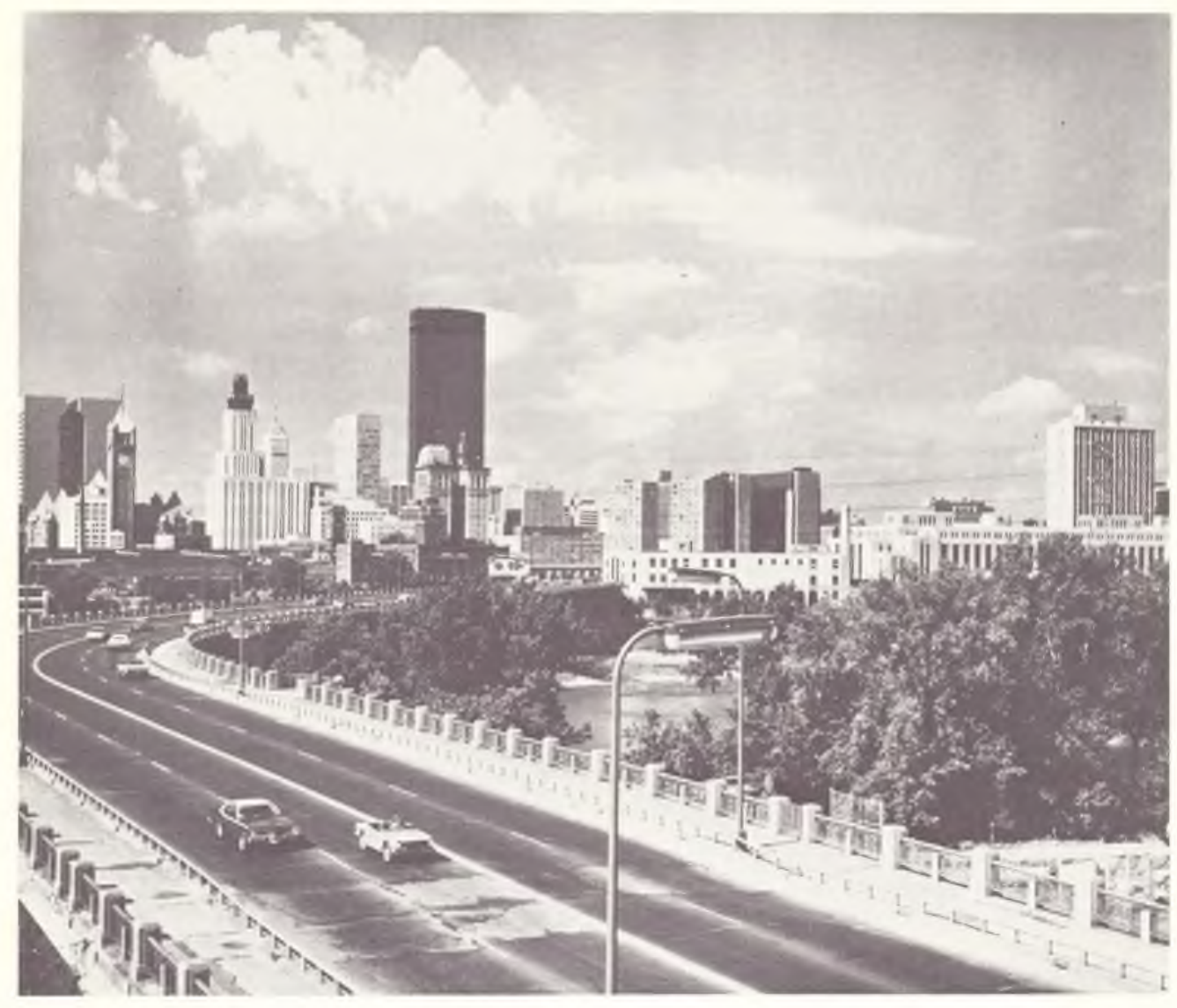

\title{
ACRL Continuing Education Courses, Minneapolis
}

\section{CE 101-EFFE(TINE SLPERIISORY SKILLS}

Date and Time: Wednesday, September 30. 1:00-5:00 p.m. Thursday, October 1, 9:00 a.m.12:00 p.m.

Instructor: Herbert S. White, dean and professor. Graduate School of Library and Information Science, Indiand University; formerly senior vice president of ISI, executive director of the NASA Scientific and Technical Information Facility. and project manager of the IBM Corporate Technical Center

Audience: For librarians who manage or are managed.

Purpose: To provide an introduction to techniques for effective supervision such as evaluating progress, determining and scheduling completion dates, and maintaining an interim report system

\section{CE 102-Working EfFectively With Grol'ps}

Date and Time: Wednesday, September 30, 9:00 a.m. $-5: 00$ p.m.

Instructor: Suzanne H. Mahmoodi, Ph.D., continuing education and library research special- ist. Office of Public Libraries and Interlibrary Cooperation, St. Paul, Minnesota.

Audience: For academic librarians without formal training in group direction and dynamics. Limited to 30 participants.

Purpose: To provide a general background in basic principles and research findings in group) behavior and enable the participant to identify and practice techniques for effectively working with a problem-solving group and for achieving quality consensus decisions.

CE I03-EstablishiNg THE COLlege BibloghapHIC: INSTRL (TION PROGRAI

ThE DiRECTOR'S ROLE

Date and Time: Wednesday, September 30 , 9:00 a.m.-5:00 p.m. Thursday, October 1, 9:00) a.m. $-12: 00$ p.m.

Instructor: Dennis E. Robison, librarian, University of Richmond.

Audience: For administrators of small and medium-size college libraries. Limited to 35 participants. 
Purpose: To provide an overall review of managerial considerations essential in establishing the successful bibliographic instruction program. Program components examined include political aspects, staff needs, budgetary support, and faculty and administration support.

\section{CE 201-An Inthoduction to Maps in Libraries: MAPS AS INFORMATION TOOLS}

Date and Time: Wednesday, September 30 , 9:00 a.m.-5:00 p.m.

Instructors: David A. Cobb, map \& geography librarian, University of Illinois-Urbana; Charles A. Seavey, government publications and maps librarian, University of New Mexico.

Audience: For academic librarians without a specialized background in maps. Limited to 35 participants.

Purpose: To explore, for the nonspecialist, the information potential of maps in the library environment. Topics to be discussed include the role of acquisitions and collection development, reference and instructional use, and space and equipment requirements.

\section{CE 202-Teaching Methods for the BibliographIC INSTRUCTION LIBKARIAN}

Date and Time: Tuesday, September 29, 1:005:00 p.m. Wednesday, September 30, 9:00 a.m.5:00 p.m. Thursday, October 1, 9:00 a.m.-12:00 p.m.

Instructor: Marilla Svinicki, assistant director, The Center for Teaching Effectiveness, The University of Texas at Austin.

Audience: For academic librarians working with or interested in bibliographic instruction.

Purpose: To provide participants with basic review and practice in learning theory and instructional methods particularly effective in the bibliographic instruction situation, with emphasis on planning and execution.

\section{CE 203-Basic ARChINES MaNagenent FOR LIBRARIES}

Date and Time: Tuesday, September 29, 1:005:00 p.m. Wednesday, September 30, 9:00 a.m.5:00 p.m. Thursday, October 1, 9:00 a.m.-12:00 p.m.

Instructors: David Horn, university archivist, DePauw University; Megan Floyd Desnoyers, Kennedy Library, National Archives, Boston.

Audience: For librarians with little or no formal archival education. Participants may have had some on-the-job experience with archives or manuscripts. They may work with archival holdings as one part of their job or they may supervise someone who has that responsibility.

Purpose: Co-sponsored by the Society of American Archivists, it will inform librarians about basic archival functions so that they will gain a better understanding of the work they do or supervise. Participation will enable library supervisors and administrators to make sound operating, budgetary, and personnel decisions in departments with archival and manuscript holdings.

\section{CE 301-Managenent Issues in Altomation AND INFORMATION TECHNOLOGY}

Date and Time: Tuesday, September 29, 9:00 a.m. $-5: 00$ p.m.

Instructor: Richard W. Boss, senior consultant, Information Systems Consultants, Inc., Bethesda, Maryland.

Audience: Library administrators who have a rudimentary knowledge of the various technologies, either from past experience or background reading. Limited to 35 participants.

Purpose: To provide an overview of library and information technology with emphasis on the administrative, economic, political, and other non-technical aspects of selecting, procuring, and using these technologies.

\section{CE 501-WRITING THE Jol RNAL ARTICLE aND Getting it Pliblished}

Date and Time: Wednesday, September 30, 9:00 a. m. $-5: 00$ p.m.

Instructor: Richard D. Johnson, director of libraries, State University College, Oneonta, New York; formerly editor, $C \& R L$, and co-editor, New horizons for academic librarians.

Audience: Librarians who wish to communicate their research, views, or studies through a journal article or review. Limited to 35 participants.

Purpose: To supply participants with an overview of the publishing process and to help them devise an effective strategy for publishing their work. Topics include selection of a publishing medium, preparation of the manuscript, submission of the manuscript, and pre- and postpublication matters.

\section{CE 502-Career advancenent in ACadenic: Librarianship: TeChniQUes for UPWARD MOBILIT}

Date and Time: Wednesday, September 30 9:00 a.m. $-5: 00$ p.m., 7:00-9:00 p.m. (optional), Thursday, October 1, 9:00 a.m.-12:00 p.m.

Instructor: Keith W. Russell, program associate, Council on Library Resources, Washington, D. C.

Audience: For academic librarians. Limited to 36 participants.

Purpose: To provide a combination of practical self-assessment and job-hunting techniques essential to successful career development and growth in the academic library environment.

Course registration fees range from \$85-\$295; advance registration is required. Attendance will be strictly limited, so plan to register early. Contact C. Brigid Welch, ACRL Headquarters, (312) 944-6780 for more information. 